\title{
The Banking Sector Role in the Rural Territories Social Development
}

\author{
Kirill Zhichkin ${ }^{1 *}$, Vladimir Nosov ${ }^{2}$ and Lyudmila Zhichkina ${ }^{1}$ \\ ${ }^{1}$ Samara State Agrarian University, 446442 Kinel, Russia \\ ${ }^{2}$ K.G. Razumovsky Moscow State University of technologies and management, 109004 Moscow, \\ Russia
}

\begin{abstract}
The article examines the features of banking services for the rural population on the example of the Samara region. The banking sector accumulates significant financial resources of the population, which can be directed to the service area development. In modern conditions, the collected funds are transferred to large cities, making rural areas even more depressed. The study purpose is to determine the features of banking services for the population in rural areas. Within the framework of this, the following tasks are being solved: - the banking services state is analyzed on the example of the Kinelsky district of the Samara region; - problems specific to rural areas are identified; - measures are proposed to solve the problems of banking services in rural areas. On the example of the Kinelsky district, it can be seen that large financial resources (more than 500 million rubles) are being withdrawn from the district with the contributions of the rural population. At the same time in rural settlements, banking services are in an inadequate state: Sberbank branches are closed or switched to part-time work. There is a low degree of provision with banking terminals, and the standards for servicing the population are not observed. As a result, the state should more actively regulate the current situation, using economic mechanisms to solve the existing social problem.
\end{abstract}

\section{Introdution}

Recently, the amount of the rural population savings in commercial banks has been increasing. So in the Samara region, only in the Kinelsky district, the savings amount that were in savings accounts with Sberbank of Russia as of 01.01.2019 amounted to 466.3 million rubles (excluding the district center) (Table 1). In addition to this, Rosselkhozbank OJSC on the same date collected savings of 51.9 million rubles.

*Corresponding author: zskirill@mail.ru 
Table 1. The amount of the Kinelsky district population savings, stored in Sberbank of Russia OJSC as of 01.01 .2019

\begin{tabular}{|c|c|c|}
\hline Branch number & Locality & Savings amount, thousand rubles \\
\hline $6991 / 0596$ & M. Malyshevka & 29062 \\
\hline $6991 / 0598$ & Krasnosamarskoe & 33012 \\
\hline $6991 / 0599$ & Bobrovka & 28399 \\
\hline $6991 / 0600$ & Komsomolsky & 100508 \\
\hline $6991 / 0601$ & Chubovka & 69261 \\
\hline $6991 / 0602$ & Buzaevka & 16453 \\
\hline $6991 / 0603$ & Alakaevka & 10464 \\
\hline $6991 / 0604$ & Bogdanovka & 25063 \\
\hline $6991 / 0605$ & N. Sarbay & 13288 \\
\hline $6991 / 0606$ & Georgievka & 92400 \\
\hline $6991 / 0607$ & Domashka & 48342 \\
\hline & TOTAL & 466252 \\
\hline
\end{tabular}

Since most of these funds are transferred from the region to large centers (Samara, Moscow), we can say that the region's economy is losing about half a billion rubles, which could effectively work for the territory benefit. For comparison, the only agricultural credit cooperative operating on the territory of this district for the whole of 2018 attracted savings in the amount of 13.0 million rubles, which is the best indicator among credit cooperatives in the region [1-5].

\section{Materials and methods}

The banking sector accumulates significant financial resources of the population, which can be directed to the service area development. In modern conditions, the collected funds are transferred to large cities, making rural areas even more depressed. The study purpose is to determine the features of banking services for the population in rural areas. Within the framework of this, the following tasks are being solved:

- the banking services state is analyzed on the example of the Kinelsky district of the Samara region;

- problems specific to rural areas are identified;

- measures are proposed to solve the problems of banking services in rural areas.

The research methodology consists in analyzing the features of the banking system for the rural population in relation to the conditions of the Samara region. In the course of the study, the abstract-logical method, situational and system analysis, economic and statistical methods, and the method of expert assessments were used.

\section{Results and discussion}

Despite this, commercial banks can leave rural residents without the necessary banking services or make them less accessible (especially for people with limited mobility, such as pensioners) [6-9]. Recently, there has been a tendency to "optimize" the branch structure of commercial banks, mainly at the expense of rural areas (liquidation of branches, reduction in the number of working days, etc.) (Table 2). 
Table 2. Schedule of work of the divisions of Sberbank of Russia in large and medium-sized settlements of the Kinelsky district

\begin{tabular}{|c|c|c|c|}
\hline The settlement & $\begin{array}{c}\text { Number of residents } \\
\text { as of 01.01.2019, } \\
\text { persons }\end{array}$ & $\begin{array}{c}\text { Number of working } \\
\text { days }\end{array}$ & Full (part-time) day \\
\hline Alakaevka & 1140 & 1 & full \\
\hline Bogdanovka & 2049 & 4 & no data \\
\hline Bobrovka & 3168 & 3 & part-time \\
\hline Parfenovka & 3353 & missing & full \\
\hline Domashka & 2224 & 4 & no data \\
\hline Kinelsky & 1850 & missing & no data \\
\hline Krasnosamarskoe & 2502 & 4 & full \\
\hline M. Malyshevka & 1465 & 4 & 1 \\
\hline N. Sarbay & & &
\end{tabular}

As a result, the rural population either remains without access to banking services at all, or is forced to go to the district center [10-16]. Let us consider the situation in the Samara region using the example of two main banks - Sberbank of Russia and Rosselkhozbank. The first, not being in the literal sense of a specialized agricultural credit institution, has received a developed branch network since soviet times. At that time, savings banks were located in medium and large settlements, which made their services accessible to all groups of the rural population. The second (Rosselkhozbank) - being created from scratch - locates its branches only in regional centers. Banking standards in the Russian Federation are not legally defined. The mandatory standards of the Central Bank of the Russian Federation include such as: capital adequacy ratio, liquidity standards. In addition, banks must comply with the following standards: maximum exposure to one borrower and a group of related borrowers; the maximum size of large credit risks; the maximum amount of loans, bank guarantees and sureties provided by the bank to its participants; the aggregate amount of risk for the bank's insiders; the standard for using the bank's own funds to acquire shares of other legal entities. [17-22]

At the same time, urban planning standards provide for the presence in rural settlements of 1 operational place for 1-2 thousand people [23-29]. As can be seen from the data for the Kinelsky district of the Samara region, this standard is not observed anywhere, which complicates the availability of banking services for the population.

To solve this problem, several possible ways are proposed that are not currently implemented in practice:

1. Creation of mobile banking points based on machines specially equipped for these purposes. The organization of such a service will provide banking services to the maximum number of rural residents. For example, for the Kinelsky district (with the existing banking infrastructure), the formation of one such point is sufficient to cover all rural settlements where banking services are not currently available [30-32];

2. installation of ATMs. The main requirement is the preliminary conclusion of service contracts - from 1000 and more. In the most favorable cases - if the administration provides protected areas for placing an ATM - the number of contracts can be reduced to 400. Even for a large settlement (with a population of 1500-2000 people) this requirement is practically impossible. Certain groups of the population, such as children, pensioners, who make up more than half of the rural population, do not have the opportunity or motivation to conclude such agreements. To implement this measure, it is necessary to develop a special regional program for installing ATMs and issuing bank cards to various groups of the population;

3. development of measures to compensate for costs for planned unprofitable branches. A similar practice existed in relation to planned loss-making stores of the consumer 
cooperation system in the Samara region [33]. It is difficult to say how legitimate such practice is in relation to commercial banks, since the functions performed by these structures are diametrically opposite. This allows us to talk about the social burden in relation to commercial banks and their obligation to fulfill the functions of providing the population with banking services. A similar experience exists in a number of countries, for example, in China, when financial institutions (for example, insurance companies), in order to be admitted to attractive markets, must also perform social functions associated with unprofitable agricultural insurance [34-37];

4. expanding the functions of agricultural credit cooperatives, at least in relation to their members. Expanding the list of functions of agricultural cooperation (at least up to the volume of credit cooperatives of citizens) will not only provide the population with the necessary services, but also further stimulate the development of this sector.

\section{Conclusion}

In modern conditions, banking services play an important role in the daily life of the rural population. On the example of the Kinelsky district, it can be seen that large financial resources (more than 500 million rubles) are being withdrawn from the district with the contributions of the rural population. At the same time in rural settlements, banking services are in an inadequate state: Sberbank branches are closed or switched to part-time work. There is a low degree of provision with banking terminals, and the standards for servicing the population are not observed. As a result, the state should more actively regulate the current situation, using economic mechanisms to solve the existing social problem.

\section{References}

1. V.N. Pulyaeva, A.A. Gibadullin, E.N. Kharitonova, N.A. Kharitonova, Problems And Prospects Of Electric Power Enterprises In Monotowns. The European Proceedings of Social \& Behavioural Sciences EpSBS. LVII, 801-813 (2019) doi: 10.15405/epsbs.2019.03.79

2. K. Zhichkin, A. Penkin, V. Balashenko, L. Zhichkina, Comparative characteristics of world agricultural markets using contracting and state farm support development (Russian Agribusiness Case Study). BIO Web of Conferences. 27, 00002 (2020) https://doi.org/10.1051/bioconf/20202700002

3. B. Fernández-Olit, Banking model and territorial financial inclusion during the great recession: A comparative analysis between social, cooperative and commercial banking. REVESCO Revista de Estudios Cooperativos. 135, (2020) doi: 10.5209/REVE.69187

4. D.S. Lopatkin, T.N. Shushunova, G.E. Shaldina, A.A. Gibadullin, I.L. Smirnova, Renewable and small energy development management. Journal of Physics: Conference Series. 1399, 033061 (2019). DOI:10.1088/1742-6596/1399/3/033061

5. L. Anderloni, E.M. Carluccio, Access to bank accounts and payment services. New Frontiers in Banking Services: Emerging Needs and Tailored. Products for Untapped Markets. 5-105 (2007) doi: 10.1007/978-3-540-46498-3_2

6. T. A. Verezubova, K. A. Zhichkin, A. M. Mukhitbekova, A. A. Penkin, L. N. Zhichkina, Comparative analysis of plant growth risks insurance in the Eurasian 
Economic Union countries. BIO Web of Conferences 17, 00003 (2020) doi: 10.1051/bioconf/20201700003

7. A. Lakomiak, K. A. Zhichkin, Economic aspects of fruit production: a case study in Poland. BIO Web of Conferences 17, 00236 (2020) doi: 10.1051/bioconf/20201700236

8. C. Bernad, L. Fuentelsaz, J. Gómez, Deregulation and its long-run effects on the availability of banking services in low-income communities. Environment and Planning A. 40 (7), 1681-1696 (2008) doi: 10.1068/a39222

9. J. Goddard, P. Molyneux, J.O.S. Wilson, The financial crisis in Europe: Evolution, policy responses and lessons for the future. Journal of Financial Regulation and Compliance. 17 (4), 362-380 (2009) doi: 10.1108/13581980911004352

10. M. Harris, K.C. Cox, C.F. Musgrove, K.W. Ernstberger, Consumer preferences for banking technologies by age groups. International Journal of Bank Marketing. 34 (4), 587-602 (2016) doi: 10.1108/IJBM-04-2015-0056

11. A.A. Gibadullin, V.N. Pulyaeva, E.N. Kharitonova, N.A. Kharitonova, Improvement of Territorial Electric Power Policy in Monotowns of Russia. ECO. 6, 164-181 (2019)

12. E. Horská, M. Szafrańska, R. Matysik-Pejas, Knowledge and financial skills as the factors determining the financial exclusion process of rural dwellers in Poland. Agricultural Economics (Czech Republic). 59 (1), 29-37 (2013) doi: 10.17221/9/2012agricecon

13. R.P. Zurdo, Y.F. Torres, M.G. Fernández, Cooperative banking and digital transformation: Towards a new relationship model with members and clients. REVESCO Revista de Estudios Cooperativos. 129, 161-182 (2018)

14. A. Lakomiak, K. A. Zhichkin, Photovoltaics in horticulture as an opportunity to reduce operating costs. A case study in Poland. Journal of Physics: Conference Series. 1399, 044088 (2019) doi:10.1088/1742-6596/1399/4/044088

15. L. Papi, E. Sarno, A. Zazzaro, The geographical network of bank organizations: Issues and evidence for Italy. Handbook on the Geographies of Money and Finance. 156-196 (2017) doi: 10.4337/9781784719005

16. J.R.S. Palacio, S.R. Pérez, Corporate social responsibility in banking. Its application to the case of the cooperative bank. REVESCO Revista de Estudios Cooperativos. 127, 204-227 (2018) doi: 10.5209/REVE.59771

17. A. Banerjee, E. Duflo, R. Glennerster, C. Kinnan, The miracle of microfinance? Evidence from a randomized evaluation. American Economic Journal: Applied Economics. 7 (1), 22-53 (2015) doi: 10.1257/app.20130533

18. R. Burgess, R. Pande, Do rural banks matter? Evidence from the Indian social banking experiment. American Economic Review. 95 (3), 780-795 (2005) doi: $10.1257 / 0002828054201242$

19. K. Zhichkin, V. Nosov, L. Zhichkina, Waste management system in the brewing industry / // IOP Conference Series: Earth and Environmental Science. 337, 012009 (2019) doi:10.1088/1755-1315/337/1/012009

20. I.A. Ivanova, V.N. Pulyaeva, L.V. Vlasenko, A.A. Gibadullin, M.I. Sadriddinov, Digitalization of organizations: current issues, managerial challenges and socioeconomic risks. Journal of Physics: Conference Series. 1399, 033038 (2019) doi:10.1088/1742-6596/1399/3/033038 
21. A. Douglas, J. Doris, B. Johnson, Corporate social reporting in Irish financial institutions. TQM Magazine. 16 (6), 387-395 (2004) doi: 10.1108/09544780410563301

22. P. Esteban-Sanchez, M. de la Cuesta-Gonzalez, J.D. Paredes-Gazquez, Corporate social performance and its relation with corporate financial performance: International evidence in the banking industry. Journal of Cleaner Production. 162, 1102-1110 (2017) doi: 10.1016/j.jclepro.2017.06.127

23. M. Habib-Uz-Zaman Khan, A.K. Halabi, M. Samy, Corporate social responsibility (CSR) reporting: A study of selected banking companies in Bangladesh. Social Responsibility Journal. 5 (3), 344-357 (2009) doi: 10.1108/17471110910977276

24. L.M. McDonald, S. Rundle-Thiele, Corporate social responsibility and bank customer satisfaction: A research agenda. International Journal of Bank Marketing. 26 (3), 170182 (2008) doi: 10.1108/02652320810864643

25. J.C. Alberdi Collantes, Intervention in rural soil, fundamental for the development of a sovereign food model. Lurralde: Investigacion y Espacio. 41, 299-322 (2018)

26. J.R.S. Palacio, V.C. Climent, Economy for the common good and ethical finances. CIRIEC-Espana Revista de Economia Publica, Social y Cooperativa. 93, 241-264 (2018) doi: 10.7203/CIRIEC-E.93.11012

27. V. Nosov, M. Tindova, K. Zhichkin, M. Mirgorodskaya, Application development for accidental pollution assessment on chemical manufacturers (pollution from chemical waste). IOP Conference Series: Earth and Environmental Science. 337, 012014 (2019) doi:10.1088/1755-1315/337/1/012014

28. E.A. Segura, M.C. VallsMartínez, Strategic analysis of Ethical Banking in Spain through Triodos Bank. Financing social and environmental projects. CIRIEC-Espana Revista de Economia Publica, Social y Cooperativa. 92, 87-120 (2018) doi: 10.7203/CIRIEC-E.92.10805

29. P. Bagus, D. Howden, Some ethical dilemmas of modern banking. Business Ethics. 22 (3), 235-245 (2013) doi: 10.1111/beer.12025

30. J. Belás, Social responsibility and ethics in the banking business: Myth or reality? A case study from the Slovak Republic. Economic Annals. 57 (195), 115-138 (2013) doi: 10.2298/EKA1295115B

31. O. Sallyanne Decker, Corporate social responsibility and structural change in financial services. Managerial Auditing Journal. 19 (6), 712-728 (2004) doi: 10.1108/02686900410543840

32. F.J. Forcadell, E. Aracil, European Banks' Reputation for Corporate Social Responsibility. Corporate Social Responsibility and Environmental Management. 24 (1), 1-14 (2017) doi: 10.1002/csr.1402

33. R.G.-A. Díaz, R. Sánchez, C. RodríguezMorilla, The economy for the common good at a local level. CIRIEC-Espana Revista de Economia Publica, Social y Cooperativa. 1 (90), 189-222 (2017) doi: 10.7203/CIRIEC-E.90.8898

34. V.G. Calvo, R.G.-Á. Díaz, The economy for the common good and the social and solidarity economies, are they complementary? CIRIEC-Espana Revista de Economia Publica, Social y Cooperativa. 87 (1), 257-294 (2016)

35. J.R.S. Palacio, E.P. García, Ethic bank and cooperative bank. A comparative analysis through the study of Caixa Popular and Ethical Banking Fiare. REVESCO Revista de Estudios Cooperativos. 124, 152-174 (2017) doi: 10.5209/REVE.54921 
36. V. Nosov, N. Kiseleva, O. Tretykova, H. Aydinov, M. Mirgorodskaya, Analysis of Recent Developments in the Russian Banking Sector. Proceedings of the 34th International Business Information Management Association (IBIMA): Vision 2025: Education Excellence and Management of Innovations through Sustainable Economic Competitive. 4310-4315 (2019)

37. E. A. Ivanova, A. A. Golovin, A. A.Kamalova, B. T. Gali, V. V. Nosov, M. V. Solovyanova, Problemas de empréstimos e maneiras inovadoras de melhorar a regulamentação financeira dos bancos comerciais. Laplage Em Revista. 6(Extra-B), 267-278 (2020) https://doi.org/10.24115/S2446-622020206Extra-B670p.267-278 